International Journal of Instruction e-ISSN: 1308-1470 • www.e-iji.net

Article submission code: 2019111608443

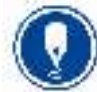

January $2021 \bullet$ Vol.14, No.1

p-ISSN: 1694-609X

pp. 779-794

Received: 16/11/2019

Revision: 30/07/2020
Accepted: 21/08/2020

OnlineFirst:15/11/2020

\title{
Blended Learning Integrated with Innovative Learning Strategy to Improve Self-Regulated Learning
}

\section{Arsad Bahri}

Dr., S.Pd, M.Pd, Universitas Negeri Makassar, Indonesia, arsad.bahri@ unm.ac.id

Irma Suryani Idris

Dr., M.Kes., Sp.K.K., Universitas Negeri Makassar, Indonesia, irmaidris@unm.ac.id

Hasmunarti Muis

S.Pd, M.Pd, SMA Negeri 6 Maros, Indonesia, hasmunartimuis@gmail.com

Muh. Arifuddin

Graduate Student, Universitas Negeri Makassar, Indonesia,

arifuddinmuh432@gmail.com

Muh. Jibran Nidhal Fikri

Graduate Student, Universitas Negeri Makassar, Indonesia,

muhjibrannidhal@gmail.com

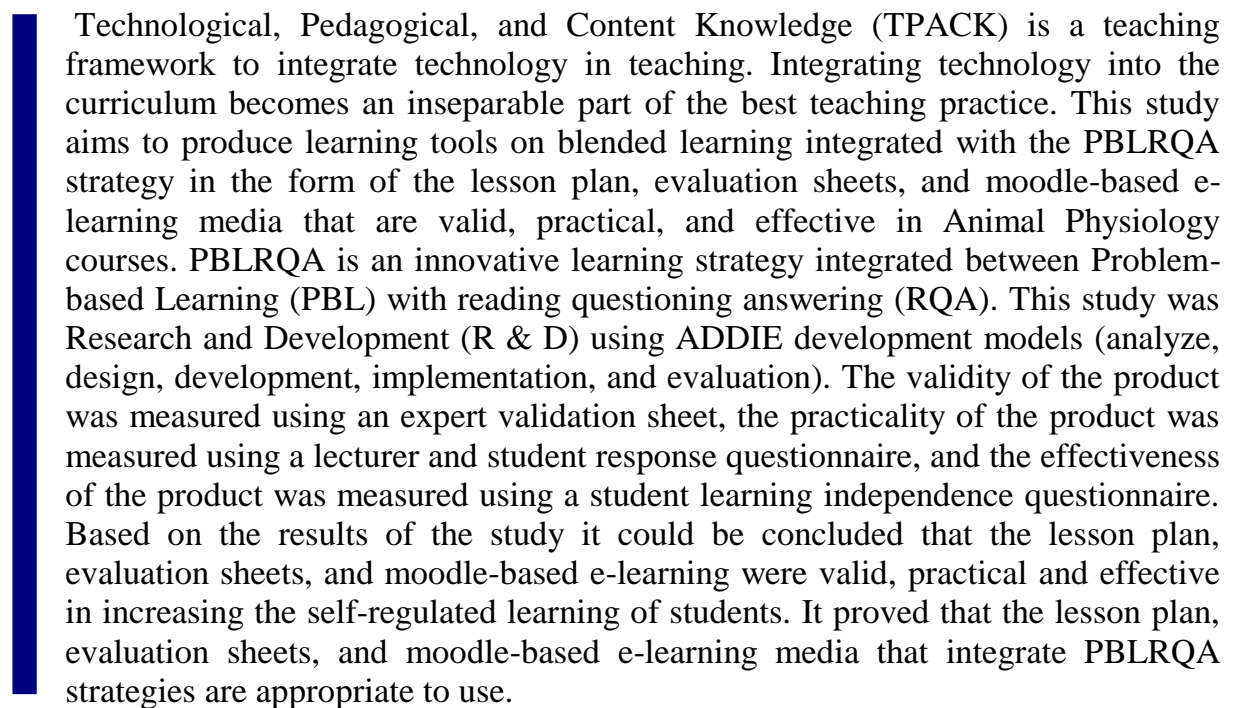

Keywords: blended learning, problem-based learning, reading questioning answering, flip classroom, self-regulated learning

Citation: Bahri, A., Idris, I. S., Muis, H., Arifuddin, M., \& Fikri, M., J., N. (2021). Blended Learning Integrated with Innovative Learning Strategy to Improve Self-Regulated Learning. International Journal of Instruction, 14(1), 779-794. https://doi.org/10.29333/iji.2021.14147a 


\section{INTRODUCTION}

Technological, Pedagogical, and Content Knowledge (TPACK) is a framework for designing new learning models by integrating technology in the learning process. There is a strong global trend towards utilizing learning management systems (LMS) in academic institutions as part of the education management system to enhance teaching and experience in the higher education (Aldiab, et. al. 2019). Integrating technology into the curriculum becomes an inseparable part of good teaching (Mills, 2006). One example of the application of technology in learning is the idea offered by NACOL (North American Council for Online Learning), which is a mixed learning model or blended learning. In this model, learning is not only focussed on face-to-face activities in the classroom, but also uses web-based technology (online learning) to support learning activities in the classroom. Blended learning combines conventional learning (face to face) with online learning (e-learning) that uses the internet in its application (Chaeruman, 2011; Sharma, 2010; Tao, et. al., 2011; Liu, et. al., 2016; Ghanem and Hamayil, 2011).

Blended learning has a basic framework of concept development based on constructivist learning perspectives that provide experience with investigations that ensure concepts are built and assimilated deeply and meaningfully (Garrison \& Vaughan, 2008). The results of meta-analysis from several studies on blended learning (Vaughan, 2007; Kim \& Bateman, 2010; Shroff, \& Deneen, 2011; Rosenthal \& Weitz, 2012; Kirna, 2013) have confirmed the effectiveness of this technology-assisted learning. Blended learning is more effective in improving learning outcomes than online and face-to-face learning that is done separately (Means, et al., 2014). At present and in the future blended learning can be an alternative solution and technology for use in the lecture process, including the Biological course i.e. Animal Physiology course.

The Animal Physiology course has various concepts relating to the processes that occur in the animal's body and the interrelationships between systems that form a unified system on animals. The scope of study material is complex, not supported by the number of effective hours of lectures which are only 100 minutes per meeting, during fourteen lectures in one semester causing the lecturers difficulty in explaining lecture material in detail to students. In addition to examining the characteristics of the subject matter material in Animal Physiology, to understand the physiology process is not only enough to get an explanation from the lecturer but also could be visualized through the media in the form of video. Students must also be active in finding information related to lecture material through reading activities. In addition, supporting facilities for the application of blended learning are very adequate, because most of students have already owned laptops or smartphones. To optimize the potential of blended learning in increasing learner learning independence, it is necessary to integrate appropriate learning strategies in both online and face-to-face lectures. One of the strategies that was considered appropriate to increase self-regulated learning of students is the PBLRQA (ProblemBased Learning and Reading, Questioning \& Answering) strategy.

Bahri \& Idris (2018) research results show that the PBLRQA strategy that integrates PBL and RQA complement each other and optimize the potential of both in empowering 
the self-regulated learning of students. The PBL and RQA syntax in PBLRQA has the same goal of developing self-directed learning so that students can be responsible for organizing and controlling their learning process (self-regulated). Self-regulated learning was essential for academic success; therefore supporting, to improve and maintain self-regulated learning skills was important (Vanslambrouck, et al., 2019). Self-regulated learning was an important variable for success, especially in blended education (Vanslambrouck, et al., 2019). According to Corebima (2009), self-regulated learning could be empowered or trained through certain strategies or efforts.

\section{METHODS}

This study was a Research and Development (R\&D) that aimed to produce learning tools in the form of the lesson plan, evaluation sheets, and moodle based e-learning media (https://fiswanbiounm.com) that are valid, practical, and effective in the Animal Physiology course. This development research procedure referred to the ADDIE development model (Grafinger, 1988) which includes the stages of analysis, design, development, implementation, and evaluation.

\section{Sample and Sampling Technique}

The population of this study were all the 4th-semeter students majoring Biology Teaching in Biology Department, The Faculty of Mathematics and Natural Sciences, State University of Makassar, Indonesia who took Animal Physiology courses as many as 67 students. The samples in this study were 20 students. The sampling technique used in this study was randomized sampling for limited testing of products.

\section{The Research Instrument, Validity, and Reliability}

The instruments used in this research were observation sheets, interview sheets, validation assessment sheets, product practicality assessment sheets, and effectiveness tests. The observation was carried out on 67 students as the population of this research by using observation sheets. Observation sheets were used to find out the learning difficulties experienced by students in the lecture process and how their responses, interests and experiences in using interactive media such as laptops and smartphones. Interview sheets are used to obtain data on the needs of three Animal Physiology lecturers in the lecture process as well as problems that often occur in lecture activities. Validation assessment sheets were used to obtain product validity data according to two experts. The assessment sheet in the form of a product practicality questionnaire was used to obtain product practicality data according to 20 students and three lecturers of Animal Physiology course in the limited testing. The self-regulated learning questionnaire was adapted from MAI (Schraw \& Dennison, 1994) and SEMLI-S (Thomas, et al, 2008) was used to obtain product effectiveness data in improving selfregulated learning of students. The indicators of this questionnaire were: 1) choose own learning activity, 2) effort to gain success, 3) initiative ability, 4) self-controlling, and 5) confidence. All instruments were valid and reliable before use. The original questionnaire was 34 items and the researches made change on the instruments by reducing as much as 4 items questionnaire to 30 valid and reliable items. 


\section{Research Procedure}

The stages include: 1) needs analysis included student analysis, content analysis, structure analysis, and set development goals and learning objectives to align with the objectives to be achieved, 2) making a design of learning tools in the form of the lesson plan, evaluation sheets, moodle design for online learning, learning independence questionnaire, lecturer response questionnaire and student responses, and research instrument design in the form of validation instruments of the lesson plan, validation instruments of evaluation sheet, validation instruments of moodle-based e-learning, and validation instruments of the questionnaire, 3) developing the learning tools (lesson plan and evaluation sheets) and moodle-based e-learning, and research instruments, 4) implementing the validated products for practicality tests through lecturer and students responses, and 5) evaluating products to obtain conclusions or a process for revising the entire product of integrated blended learning with PBLRQA strategy in Animal Physiology course, which is carried out after seeing validity test results and practicality of products.

\section{Data Analysis}

The data were collected in the form of quantitative data, and analyzed descriptively, equipped with triangulation of methods and data sources. Data analysis included: 1) The validity data of the products produced are analyzed and adjusted to the validity category according to Hobri (2010), i.e. strongly valid (4.6 to 5), valid (3.6 to 4.5), less valid (2.6 to 3.5 ), invalid (1.6 to 2.5 ), and strongly invalid (less than 1.6). 2) Practicality data of the product produced in the form of questionnaire data responses of lecturers and students who were analyzed quantitatively (percentage). The analysis to calculate the percentage of lecturer and student responses positively was adapted from Arikunto (2009), which is very practical (84 \%-100\%), practical (68\%-83\%), quite practical (52\%-67\%), less practical (36\%-51\%), and impractical (less than 35\%). Blended learning can be declared practical if the response of lecturers and students reached a minimum of $68 \%$ or is in the practical category. The data effectiveness of the product developed was analyzed by quantitative descriptive analysis using $\mathrm{N}$-gain. The normalized gain rule ( $\mathrm{N}$-gain) was developed by (Hake, 1999) namely the $\mathrm{N}$ score gain $\leq 0.30$ in the low increase category, $0.30<\mathrm{N}$ gain $\leq 0.70$ in the medium increase category, and $0.70<\mathrm{N}$ gain $\leq 1.00$ height increase category.

\section{FINDINGS}

\section{Analysis}

Researcher collected information in the field through initial observation, distribution of questionnaires and interviews with lecturers and distribution of questionnaires to students. The needs analysis was done to gather information related to the needs of students and the needs of lecturers in the lecture process.

Based on the observation, it was found that the current problems that often occur in the lecture process are students having difficulty in taking important ideas and remembering the material. It caused by the characteristics of Animal Physiology material are quite 
complex and contain many abstract concepts and involves a variety of organ system work mechanisms that require high imagination and reasoning abilities. In fact, the restricted time allotment in the lecture process becomes an obstackle for lecturers to explain lecture material in detail to students so that they often provide additional homework at home to learn independently to enhance their understanding on the material. Therefore, a new innovation are needed in the lecture process to facilitate the students learning needs in Animal Physiology course so that the goals of lectures can be achieved.

Based on an analysis of the students'needs in Biology Department especially for 67 students of fourth semester who took Animal Physiology course, the aspects needed are presented in Table 1

Table 1

The result of needs analysis

\begin{tabular}{lll}
\hline Aspect & Number of Students & Percentage (\%) \\
\hline Need a variety of media and learning resources & 60 & 89.55 \\
\hline Need an enrichment of lecture material at home & 63 & 94.03 \\
\hline Need an innovation in learning & 63 & 94.03 \\
\hline Want to try online learning & 52 & 77.61 \\
\hline
\end{tabular}

Analysis of students was done based on the results of interviews with lecturers and the questionnaires distributed to the students. The results of student analysis are presented in Table 2.

Table 2

The result of student analysis

\begin{tabular}{lll}
\hline Aspect & Number of Students & Percentage (\%) \\
\hline Students have smartphone & 64 & 95.52 \\
\hline Students have a laptop & 63 & 94.03 \\
\hline Students have wifi at home & 22 & 32.84 \\
\hline Using data cellular & 63 & 94.02 \\
\hline Adept at operating a laptop & 53 & 79.10 \\
\hline Access internet to do the assigments & 64 & 95.52 \\
\hline Access internet to browse the course material & 60 & 89.55 \\
\hline
\end{tabular}

Material content analysis was done by reviewing the material of Animal Physiology course. The result of content analysis in Animal Physiology courses consisted of Animal Physiology and Homeostasis Concept, Nervous System, Sensory System, Hormone System, Motion System, Respiration System, Excretion System, Digestive System, Reproduction System, Circulation System, Osmoregulation, and Thermoregulation.

The development of blended learning can ease the lecturers to carry out lectures and can optimize the learning process outside of face-to-face lecture so that students can learn without being limited by space and time while still connected to the internet connection. 


\section{Design}

The design was used to guide the development implementation to be more structured can be seen in Table 3 .

Table 3

Development Design

\begin{tabular}{|c|c|}
\hline \multicolumn{2}{|c|}{ Development Design } \\
\hline $\begin{array}{l}\text { Name of } \\
\text { Design }\end{array}$ & $\begin{array}{l}\text { Blended Learning integrated with PBLRQA strategy in Animal Physiology } \\
\text { courses }\end{array}$ \\
\hline $\begin{array}{l}\text { Design } \\
\text { Sponsor }\end{array}$ & Indonesian Ministry of Research, Technology, and Higher Education \\
\hline $\begin{array}{l}\text { Customer } \\
\text { Need }\end{array}$ & $\begin{array}{l}\text { Innovative media and learning resource that can facilitates independent and } \\
\text { collaborative learning }\end{array}$ \\
\hline $\begin{array}{l}\text { Reason of } \\
\text { Design }\end{array}$ & $\begin{array}{l}\text { The integration of blended learning with PBLRQA strategy has not been } \\
\text { implemented in the Animal Physiology course. }\end{array}$ \\
\hline $\begin{array}{l}\text { Expected } \\
\text { Result }\end{array}$ & $\begin{array}{l}\text { Blended Learning integrated with PBLRQA strategy is valid, practical, and } \\
\text { effective }\end{array}$ \\
\hline Customer & $\begin{array}{l}\text { The fourth semester students at Department of Biology, Faculty of } \\
\text { mathematics and Natural Sciences, The State University of Makassar }\end{array}$ \\
\hline Design Aim & $\begin{array}{l}\text { Producing the valid, practical and effective lesson plan, evaluation sheet, and } \\
\text { moodle-based e-learning as an innovative learning resource and media that } \\
\text { giving a chance for students to learn independently and collaboratively. }\end{array}$ \\
\hline $\begin{array}{l}\text { Knowledge, } \\
\text { skills, and } \\
\text { abilities of } \\
\text { customer }\end{array}$ & $\begin{array}{l}\text { Students have knowledge, skills and abilities in operating computers so that } \\
\text { students have no difficulty in using moodle when learning online. }\end{array}$ \\
\hline Feedback & $\begin{array}{l}\text { Lecturers can implement learning tools that support blended learning. } \\
\text { Students can learn independently, collaboratively and effectively to build their } \\
\text { own knowledge. }\end{array}$ \\
\hline Time limit & 3 months \\
\hline Design benefit & $\begin{array}{l}\text { Build students' independent learning abilities. In addition, the design results } \\
\text { are made to develop existing learning resources to be more innovative. And } \\
\text { make it easier for lecturers to implement blended learning that refers to the } \\
\text { learning tools that have been made. }\end{array}$ \\
\hline
\end{tabular}

The form of the lesson plan used refers to the form of the lesson plan that were applied at the State University of Makassar including the components of identity, learning outcomes (knowledge, skills, and attitudes), expected end ability, learning material, learning activities, time allotment, students' learning experience, assessment criteria and indicators, and scoring and weighting criteria. The e-learning design format using moodle is shown in Table 4. 
Table 4

A design of moodle-based e-learning

\begin{tabular}{ll}
\hline Component of E-learning & Sub component of E-learning \\
\hline Homepage (log in page) & $\begin{array}{l}\text { name of e-learning site, log in of account, \& information of e- } \\
\text { learning }\end{array}$ \\
\hline Main page (Dashboard) & $\begin{array}{l}\text { name of e-learning site, lesson plan, special summary, online } \\
\text { visitors, setting, search, calendar, site home, site page, \& course } \\
\text { page }\end{array}$ \\
\hline Site home & learning resources \& learning activities \\
\hline Site page & $\begin{array}{l}\text { class member, blog sites, plan sites, notes, search, calender, \& } \\
\text { administration }\end{array}$ \\
\hline Course page & online member, quiz, \& score \\
\hline
\end{tabular}

\section{Development}

At this stage, the products developed are learning tools (lesson plan and evaluation sheets) and moodle-based e-learning. The moodle-based e-learning developed, can be accessed via http://fiswanbiounm.com. The results of developing moodle-based elearning can be seen on (1) the front page (login page), (2) the main page (dashboard), and (3) the course page. The course feature provides 12 meetings in the learning process. Every moodle-based online learning meeting is provided with learning resources and learning activities. The forms of learning resources are available are in the form of word and pdf document. format. Also equipped with a video and url. Each meeting also features a discussion forum, chat, assignments and quizzes at the end of online learning. Learning activities in moodle-based e-learning in the form of multiple choice and essays questions that will be completed by students in accordance with the specified time. The features provided in e-learning are features that will be adjusted to fulfill the needs of lecturers and students in the learning process. Display e-learning can be accessed through http://fiswanbiounm.com.

The products developed were validated by an expert. Results of expert validation on learning tools and moodle-based e-learning. Validation was carried out by reviewing the product of development results in the form of the lesson plan, evaluation sheets, and moodle based e-learning and its validation instruments. The validity of the lesson plan was analyzed based on the results of the validation by two expert validators can be seen in Table 5. Table 5 shows the average score on all aspect of validation of the lesson plan were strongly valid. 
Table 5

The result of validation of the lesson plan

\begin{tabular}{lll}
\hline Aspect & Average Score & Category \\
\hline The identity of the lesson plan & 5 & strongly valid \\
\hline $\begin{array}{l}\text { Learning achievement competencies include attitudes, } \\
\text { knowledge and skills }\end{array}$ & 5 & strongly valid \\
\hline $\begin{array}{l}\text { The final competency that is expected to be owned by } \\
\text { students }\end{array}$ & 5 & strongly valid \\
\hline Development of course material & 4.70 & strongly valid \\
\hline Development of learning activities & 4.63 & strongly valid \\
\hline $\begin{array}{l}\text { Learning experiences for students are formulated in } \\
\text { accordance with the characteristics of students and } \\
\text { formulated in operational verbs that can be measured and } \\
\text { observed as a reference for assessment }\end{array}$ & 5 & strongly valid \\
\hline The assessment is based on certain criteria and indicators & 5 & \\
\hline Time Allocation & 4.75 & strongly valid \\
\hline $\begin{array}{l}\text { Can be used as a reference in the preparation of student } \\
\text { worksheets and research instruments }\end{array}$ & 5 & strongly valid \\
\hline Average & 4.89 & strongly valid \\
\hline
\end{tabular}

The assessment of moodle-based e-learning is carried out by two expert validators by filling in the assessment sheets. The results of the assessment of the two expert validators are described in Table 6 . Table 6 shows that the average scores of validation of e-learning strongly valid.

Table 6

The result of validation of $e$-learning

\begin{tabular}{lll}
\hline Aspect & Average score & Category \\
\hline Learning display & 5 & strongly valid \\
\hline Content eligibility & 4.25 & valid \\
\hline Concepts organization concepts & 4.50 & strongly valid \\
\hline Design & 4.30 & valid \\
\hline Steps of learning activities & 4.75 & strongly valid \\
\hline The constructivist paradigm & 4.60 & strongly valid \\
\hline Language & 4.50 & strongly valid \\
\hline Average & 4.56 & strongly valid \\
\hline
\end{tabular}

Analysis of the results of the validation of the two expert validators on the evaluation sheet is shown in Table 7 . Table 7 shows that the average scores of validations of the evaluation sheet is strongly valid. 
Table 7

The result of validation of evaluation sheet

\begin{tabular}{lll}
\hline Aspect & Score & Category \\
\hline Material content & 4.75 & strongly valid \\
\hline Rubric & 4.75 & strongly valid \\
\hline Construct & 5 & strongly valid \\
\hline Language & 4.5 & strongly valid \\
\hline Average & 4.75 & strongly valid \\
\hline
\end{tabular}

Analysis of the results of the validation of the two expert validators on the self-regulated learning questionnaire is shown in Table 8. Table 8 shows that the average scores of validation of self-regulated learning questionnaire is strongly valid.

Tabel 8

The result of validation of self-regulated learning questionnaire

\begin{tabular}{lll}
\hline Aspect & Score & Category \\
\hline Instruction & 5 & strongly valid \\
\hline Questionnaire component coverage & 4.50 & strongly valid \\
\hline Language & 4.50 & strongly valid \\
\hline Average & 4.67 & strongly valid \\
\hline
\end{tabular}

\section{Implementation}

The implementation process was carried out after the development process was completed. At this phase, includes practicality tests of products that have been previously validated at the development phase. Practicality test was conducted by 3 lecturers through lecturer response questionnaire. Furthermore, a practicality test was also conducted by analyzing the response data of 20 students through the questionnaire. The questionaire for practicality testing consisting of lecturer responses and student responses were valid and reliable. The practicality test results of moodle-based elearning were assessed by the lecturer and can be seen in Table 9.

Table 9

The result of lecturer responses toward e-learning

\begin{tabular}{lll}
\hline Aspect & Responses Percentage (\%) & Practical Category \\
\hline Learning display & 91.11 & very practical \\
\hline Content feasibility & 78.09 & practical \\
\hline Display & 88.89 & very practical \\
\hline Operation & 90.67 & very practical \\
\hline Language & 86.67 & very practical \\
\hline Software engineering & 91.67 & very practical \\
\hline Average & 87.85 & very practical \\
\hline
\end{tabular}

The results of practicality test of the moodle-based e-learning conducted by fourth semester students who took Animal Physiology course in Biology Department, Faculty of Mathematics and Natural Sciences, the State University of Makassar are shown in Table 10 . 
Table 10

The result of students responses toward e-learning

\begin{tabular}{lll}
\hline Aspect & Responses Percentage $(\%)$ & Practical Category \\
\hline Material relevance & 89.20 & very practical \\
\hline Display & 88.00 & very practical \\
\hline Operation & 68.80 & practical \\
\hline Contructivistic paradigm & 81.80 & practical \\
\hline Language & 86.67 & very practical \\
\hline Average & 82.89 & practical \\
\hline
\end{tabular}

Based on the analysis of the lecturers 'responses and the students' responses, it shows that the moodle-based e-learning product developed for blended learning is very practical and did not need to be revised.

\section{Evaluation}

This stage was a limited testing phase of using product development to test the effectiveness of the product. The research instruments were the self-regulated learning questionnaire. The results of the effectiveness test can be seen in Table 11.

Table 11

The result of the effectiveness of product

\begin{tabular}{ll}
\hline N-gain category & Percentage \\
\hline Height increase & $65 \%$ \\
\hline Medium increase & $25 \%$ \\
\hline Low increase & $10 \%$ \\
\hline Total & $100 \%$ \\
\hline
\end{tabular}

\section{DISCUSSION}

This developmental research had produced a product in the form of learning tools (lesson plan and evaluation sheets), moodle-based e-learning to support blended learning, and self-regulated learning questionnaire that have met the validity criteria. If all aspects of the assessment have reached the validity criteria, then the media developed was declared suitable for use (Hala, 2015).

The development of learning tools was carried out by integrating the PBLRQA strategy adopted in this study and producing blended learning with teaching activities that are more structured and systematic. The PBLRQA strategy adopted in this study has a syntax that aimed to develop self-directed learning so that students can be responsible for organizing and controlling their learning process. In addition, this strategy helps students to become independent and self-regulated learners.

The PBLRQA learning syntax that was developed shows that student activity begins with reading several resources, then students think about the problems found and then write them in the list of questions. Furthermore, students will discuss the tasks that have been made to clarify the answers or solutions that are unclear The end of learning was self-assessing made by each student to monitor the thought process and learning outcomes (Bahri, 2017). During PBLRQA, students are trained to learn independently, 
filter out irrelevant information while focusing on more important things, teamwork, solving and learning to apply the concept of a problem. This helps students gain more information and make them responsible for their learning.

E-learning developed for online learning is a moodle-based e-learning that can be accessed through http://fiswanbiounm.com. In the e-learning there is a combination of text, images, videos, animations, as a learning resource for students in Animal Physiology course and various activities such as quizzes, chat, glossary and discussion forums that can motivate the students to be more active. The diversity of learning resources and activities undertaken by students can help the learning process running innovatively. In line with the results of research conducted by Chou \& Chou (2011) that innovative learning could be created through three images of learning namely, face-toface learning, online learning (e-learning), and mixed learning (blended learning).

The results of the questionnaire showed that the lecturers and students gave a positive response to the learning tools and e-learning. According to Nedeva (2005), a very good response mean that students or lecturers support its use, and the students were motivated to attend lectures using e-learning.

The data also showed that some students feel free to choose their own learning activities and could increase their self-controlling by using blended learning. This is in line with the finding of Strambi \& Bauvet (2003) and Schraw (2007) found that students could control learning activities independently. Students assumed that they could control their learning by themselves through direct feedback from the e-learning and also feedback from the lecturer on the face to face learning. Students had more opportunities to interact, get direct feedback so that they could improve their learning and performance independently. Blended learning also promote collaborative activities and interactions between students through assignments inside or outside the classroom (Tan et al, 2005), and increase interdisciplinary or independence students can interact actively in the learning process. Blended learning represents clear advantages for creating learning experiences that provide the right learning at the right time for each student. Stacey \& Gerbic (2008) stated that it could make students be more communicative.

The results of the students' questionnaire in this study also showed that by using blended learning, the students had some effort to succeed in their learning and it could make students more motivated in learning. Study of Schmidt (2007), and Bart \& Baurke (2010) supported this statement that students could increase their motivation and success in learning. It means that students' learning outcomes were higher than conventional learning. Alsalhi et al., (2019) stated that blended learning as a new learning strategy that combines traditional learning in various forms and e-learning in various models, it could increase student motivation and learning achievement. Adult students in a blended learning environment tend to be efficient enough to organize their own learning (Vanslambrouck, et al., 2019). Andragogic principles of self-directed learning, lifeoriented that were more relevant to each other's experiences, and intrinsic motivation to learn something that was personally relevant was greatly facilitated through the blended learning (Cocquyt, et. Al. 2019). Blended learning has the potential to enhance learning, but there are also challenges especially in responding to the complexity of the two 
learning environments. Further research is needed to identify several factors that can determine the success of blended learning.

Integrating the PBLRQA strategy in this blended learning environment can improve learning independence not apart from the PBL stages in the PBLRQA strategy. Through the PBL phase, students are confronted with an ill-structured real-world problem, so students try to make the problem become well-structured. Students will formulate several possible hypotheses and solve them based on information from reading various literature. Learner activities in PBL involved training in self-directed learning (Downing, et al., 2009; and Corebima, 2010). The activities of students in PBL steps were the benchmark if there is metacognition in PBL. In addition, PBL enhanced selfregulation and facilitated the thinking and learning processes. Sungur \& Tekkaya (2006) mentioned that through PBL, students were proficient in process skills and problemsolving skills as well as independent learning skills.

Optimalization the empowerment of the self-regulated of students in the PBLRQA strategy is also inseparable from the RQA stage. This is in line with the results of Hasanuddin (2013) that the RQA capable to enhance self-regulated learning of students. Corebima (2010) stated that at RQA strategy, students must first carefully read the material and then arrange questions that contain problems. From reading activities, students can do self-assessing, where students will understand what is known from the reading activities that have been carried out. Sumampouw (2019) argued that making questions had two stages, the accepting stage and the challenging stage. When reading information about the situation, at that time a metacognitive step will be carried out, that is the process of receiving, while the chalenging stage is indicated when gathering questions. The reception process makes it possible to place information on a network of metacognitive structures while a challenging process can allow existing networks to have stronger relationships.

The stages of raising problems in the form of questions in the PBLRQA strategy are part of empowering self-regulated learning of students. Questions are triggers for students' thought processes. Corebima (2010) explained that an alternative to improve students' thinking skills was to ask questions that can spur thought processes. Schraw \& Moshman (1995) and Slavin (2000) found that the questioning strategy had an effect to empower self-regulated learning of students. The interaction between strategy and academic achievement influences metacognitive skills. This is due to the PBLRQA stage where the process of discussing and debating with each other, as a result student become accustomed to thinking (Bahri, et al. 2019).

The last step of the PBLRQA strategy is making summarize the results of reading and discussion. This kind of learning activity shows a self-regulated learning pattern. This is in line with the statement that summarizing was one of the learning strategies that could empower learners' metacognitive skills (Corebima, 2010). The self-regulated learning patterns will be reflected when students have discussions to get clarification. From the discussion activities students can find out the learning and what they have not known yet. With this activity, students would be able to develop into independent learners 
(Bahri, et al., 2019). This potential is believed to be even greater because the summarizing task is carried out at the end of PBLRQA learning.

PBLRQA learning that shows the pattern of training on self-regulated learning has been proven. The findings of this study are consistent with the results of Kuiper's (2002) study that used metacognitive self-regulated learning strategies to help students improve their metacognitive skills. Thus, the PBLRQA stage helps students to develop thinking skills and make students self-regulated learners. Self-regulated learning contributed to the development of metacognitive insights and strengthens the application of metacognition in the context of clinical reasoning (Chen, et al. 2019). In line with the research of Bahri, et al. (2019) that PBLRQA aimed to develop independent learning. With independent learning, students can be responsible for organizing their own learning. In addition, this strategy helped students to become independent learners. Bahri \& Corebima (2015) suggested that through the development of students' learning independence, retention and cognitive learning outcomes could be improved.

\section{CONCLUSION}

This research produced the learning tools on blended learning integrated with the PBLRQA strategy in the form of lesson plan, evaluation sheets and e-learning media based on moodle in Animal Physiology courses. Based on the results of research, it can be concluded that the products declared were valid, practical and effective. The valid and practical blended learning has proven effective to empower self-regulated learning of students. It is expected that this work contributes to the overall field of study by implementing blended learning more widely by considering the characteristics of students and also learning material.

\section{ACKNOWLEDGMENTS}

This project was supported and funded by DRPM Ministry of Research, Technology, and High Education, Republic of Indonesia. We would like to thank to everyone who who has contributed in the completion of this paper.

\section{REFERENCES}

Aldiab, A., Chowdhury, H., Kootsookos, A., Alam, F., \& Allhibi, H. (2019). Utilization of Learning Management Systems (LMSs) in higher education system: A case review for Saudi Arabia. Energy Procedia, 160, 731-737. doi: 10.1016/j.egypro.2019.02.186.

Bahri, A., \& Idris, I. S. (2017). Teaching Thinking: Memberdayakan Keterampilan Metakognitif Mahasiswa melalui PBLRQA (Teaching Thinking: Empowering Students' Metacognitive Skills through PBLRQA). Proceeding of National Seminar, Research Institution, The State University of Makassar 2017.

Bahri, A., \& Idris, I.S. (2018). Development and Validation of Learning Strategy for Metacognitive Skills Empowerment: PBLRQA (PBL integrated with Reading, Questioning, and Answering). Journal of Physics: Conf. Series, 1028. doi:10.1088/1742-6596/1028/1/012028. 
Bahri, A., Idris, I.S., Nurman, R., \& Ristiana, E. (2019). PBLRQA Strategy Potential in Enhancing Metacognitive Skills of Students with Different Academic Achievement. Journal of Physics: Conf. Series ,1317. doi:10.1088/1742-6596/1317/1/012199.

Bahri, A., \& Corebima, A. D. (2015). The contribution of learning motivation and metacognitive skill on cognitive learning outcome of students within different learning strategies. Journal of Baltic Science Education, 14(4), 487-500.

Hake, R. R. (1999). Analysing Change/Gain Score Woodland Hills Dept. of Physics. Indiana University. Bloomington.

Bart, D. \& Baurke, J. (2010). Getting Starded with Blended Learning. Australia: Griffith Institute for Higher Education.

Chaeruman, U. A. (2011). Implementing Blended Learning: A Case-Based Sharing Experience. Diakses dari http://www.teknologipendidikan.net/2011/06/ 21/implementing-blended-learning-a-case-based-sharingexperiencel accessed at 05 Februari 2018.

Chen, J. H., Björkman, A., Zhou, J. H., \& Engström, M. (2019). Self-regulated learning ability, metacognitive ability, and general self-efficacy in a sample of nursing students: A cross-sectional and correlational study. Nurse Education in Practice. 37, 1521. doi:10.1016/j.nepr.2019.04.014.

Chou, A. Y. \& Chou, D. C. (2011). Course Management Systems and Blended Learning: An Innovative Learning Approach. Decision Sciences Journal of Innovative Education, 9(3), 463-484.

Cocquyt, C., Zhu, C., Diep, A. N., De Greef, M., \& Vanwing, T. (2019). Examining The Role of Learning Support in Blended Learning For Adults' Social Inclusion and Social Capital. Computers \& Education, 142(103610).

Corebima, A.D. (2009). Jadikan Peserta Didik Pebelajar Mandiri (Making Students as Self-Regulated Learner). Paper Presented at National Seminar, The State University of Makassar, 19 December 2009.

Garrinson, D, R. \& Vaughan, N, D. (2008). Blended Learning in Higher Education: Framework, Principles and Guidelines. San Fransisco: SanJohn Wiley \& Sons, Inc.

Ghanem, F., \& Hamayil, M. (2011). Management Role of Al-Quds Open University in Leading Effective Distance Learning Programs: An Evaluation of QOU Experience in Blended Learning. Contemporary Educational Technology, 2(1), 55-76.

Grafinger, D. (1988). Basics of instructional systems development. Alexandria: American Society for Training and Development.

Hala, Y. Saenab, S., \& Kasim, S. (2015). Pengembangan Perangkat Pembelajaran Biologi Berbasis Pendekatan Saintifik pada Konsep Ekosistem Bagi Siswa Sekolah Menengah Pertama (Development of Biology Instructional Tools Based on Saintific Approach in Ecosystem Concept for Junior High School). Journal of EST, 1(3), 85 - 96. 
Hobri. (2009). Metodologi Penelitian dan Pengembangan (Developmental Research) (Aplikasi pada Penelitian Pendidikan Matematika)/Methodology of Reseach and Development (An Application on Mathematics Education Research). Jember: FKIP Jember University.

Kim, H. K. \& Bateman, B. (2010). Student Participation Patterns in Online Discussion: Incorporating Constructivist Discussion into Online Courses. International Journal on E-Learning, 9(1), 79-98.

Kirna, I M. (2013). Penerapan Strategi Problem Posing yang disampaikan secara Blended Learning pada Perkuliahan Chemical Bonding. Proceeding of National Seminar, FMIPA III Ganesha Education University, Bali, 30 November 2013.

Liu, Q., Peng, W., Zhang, F., Hu, R., Li, Y. \& Yan, W. (2016). The Effectiveness of Blended Learning in Health Professions: Systematic Review and Meta Analysis. Journal of Medical Internet Research, 18(1), 1-12.

Mills, S. C. (2006). Using the Internet for Active Teaching and Learning. New Jersey: Pearson Education.

Means, B., Toyama, Y., Murphy, R., \& Baki, M. (2014). The Effectiveness of Online and Blended Learning: A Meta-Analysis of the Emperical Literature. Teachers College Record, 115, 1-47.

Nedeva V. (2005). The Possibilities of E-Learning, Based on Moodle Software Platform. Trakia Jornal of Sciences, 3(7), 12-19.

Rosenthal, D. \& Weitz, R. (2012). Large-Course Redesign via Blended Learning: A Post-Implementation Assessment Across Institutions. International Journal on ELearning, 11(2), 189-207.

Sumampouw, H. M. (2019). Strengthening Nano Biological Education; RQA Strategy of Genetic Concept Based on Metacognitive. Journal of Physics: Conf. Series 1317. doi:10.1088/1742-6596/1317/1/012182.

Schraw, G. (2007). The Use of Computer-Based Environments for Understanding and Improving Self-Regulation. Metacognition Learning, 2, 169-176.

Schraw, G., \& Dennison, R. S. (1994) Assessing metacognitive awareness. Contemporary Educational Psychology, 19(4), 460-475.

Schmidt, J. (2007). Blogging Practices: An Analitical Framework. Journal of ComputerMediated Communication, 12(4), 1-13.

Sharma, P. (2010). Blended Learning. ELT Journal, 64(4), 456-458.

Shroff, R. \& Deneen, C. (2011). Assessing Online Textual Feedback to Support Student Intrinsic Motivation Using a Collaborative Text-based Dialogue System: A Qualitative Study. International Journal on ELearning, 10(1), 87-104. 
Stacey, E. \& Gerbic, P. (2008). Success Factors for Blended Learning. Melbourne: Education Deakin University.

Strambi, A. \& Bouvet, E. (2003). Flexibility and Interaction at a Distance: A MixedMode Environment for Language Learning. Language Learning \& Technology, 7(3), 81-102.

Tan, S., Yeo, A. \& Lim, W. (2005). Changing Epistemology of Science Learning Through Inquiry with Computer-Supported Collaborative Learning. Journal of Computers in Mathematics and Science Teaching, 24(4), 267-286.

Tao, J., Fore, C., \& Forbes, W. (2011). Seven Best Face to Face Teaching Practices in a Blended Learning Environment. Journal of Applied Learning Technology, 1(3), 20-29.

Thomas, G., Anderson, D. \& Nashon, S. (2008). Development of An Instrument Designed to Investigate Elements of Science Students' Metacognition, Self-Efficacy and Learning Processes: The SEMLI-S. International Journal of Science Education, 30(1)3, 1701-1724.

Vanslambrouck, S., Zhu, C., Pynoo, B., Lombaerts, K., Tondeur, J., \& Scherer, R. (2019). A Latent Profile Analysis of Adult Students' Online Self-Regulation In Blended Learning Environments. Computers in Human Behavior, 99, 126-136. doi:10.1016/j.chb.2019.05.021.

Vaughan, N. (2007). Perspectives on Blended Learning in Higher Education. International Journal on E-Learning, 6(1), 81-94. 